\title{
Tidlige skoleforbindelser: Svensk-norsk ideutveksling på skolens område rundt midten av det 19. århundre og dannelsen av tekstkulturer over kjølen
}

\author{
Merethe Roos
}

\begin{abstract}
When it comes to the development of school and education between 1814 and 1905, the relation between Norway and Sweden has only been superficially subject to previous research, even though sources can verify contact and transfer of ideas already as early as in the beginning of the 1850's. In this article, I will argue that Norway and Sweden are connected in common textual cultures, which gives a distinctive direction for the development of the school in the following decades. A textual culture refers to the material processes and ideological formations surrounding the production, transmission, reception, and regulation of texts. It studies the interaction between these processes and formations in order to show how texts get made and how they are understood. The textual cultures will here be studied on the background of Hartvig Nissen's articles in the newspaper Morgenbladet in 1855, as well as a discussion between the school periodicals Almueskoletidende og Den Norske Folkeskole in 1861.
\end{abstract}

Keywords • Norway (Norge), Sweden (Sverige), 19th century school (1800-tallets skole), textual cultures (tekstkulturer).

Temaet for denne artikkelen er idéutveksling på skolens område under unionstiden mellom Norge og Sverige. Mellom 1814 og 1905 var Norge og Sverige forbundet gjennom felles konge, felles utenriks- og handelspolitikk og felles flagg. Den såkalte Mossekonvensjonen august 1814 hadde innrømmet Norge stor grad av selvstendighet. Temperaturen på forholdet mellom de to landene varierte i løpet av disse årene, men fra midten av 1800-tallet og i noen år fremover så man i økende grad vilje til skandinavisk samarbeid. ${ }^{1}$ Studentmøtene, som ble holdt på 1840- og -50-tallet, ble viktige møteplasser for kulturell utveksling mellom landene, og det pan-skandinaviske fellesskapet ble fulgt opp innen kunst og vitenskap i tiårene fremover. ${ }^{2}$ Hva skolen angikk, møttes en rekke lærere til et fellesskandinavisk lærermøte i Örebro

1 Ruth Hemstad, Fra Indian Summer til nordisk vinter: Skandinavisk samarbeid, skandinavisme og unionsoppløsningen (Oslo: Akademisk publisering, 2008), 130. Se også Kari Haarder Ekman, "Mitt hems gränser vidgades": En studie $i$ den kulturella skandinavismen under 1800-talet (Göteborg/ Stockholm: Makadam Förlag og Centrum för Danmarksstudier 23, 2010); Magdalena Hillström og Hanne Sanders, red., Skandinavism: En rörelse och en idé under 1800-talet (Göteborg/Stockholm: Makadam förlag, 2014). For skandinavisme på vitenskapens område, se Johan Tønnesson, "Naturvitenskapens kommunikative landskap: Teksthistorisk blikk på det fjerde skandinaviske naturforskermøtet, Christiania 1844," i Sann opplysning? Naturvitenskap i nordiske offentligheter gjennom fire århundrer, red. Merethe Roos og Johan Tønnesson (Oslo: Cappelen Damm Akademisk, 2017), 163-90. Se også Ruth Hemstad, Jes Fabricius Møller og Dag Thorkildsen, "Skandinavismen som visjon og påvirkningskraft," i Skandinavismen: Visjon og virkning, red. Ruth Hemstad, Jes Fabricius Møller og Dag Thorkildsen (Odense: Syddansk universitetsforlag, 2018), 9-20.

2 Dag Thorkildsen, "Skandinavismen - en historisk oversikt," i Nasjonal identitet - et kunstprodukt?, red. Øystein Sørensen (Oslo: KULT’s skriftserie, 1994), 191-209.

Merethe Roos is Professor of History at University College of Southeast-Norway (USN), Norway.

Email: merethe.roos@usn.no 
i $1868 .^{3}$ Dette møtet har vanligvis vært sett som utgangspunktet for skandinavisk skolesamarbeid, og møtet var det første av sitt slag i en rekke av mange frem mot århundreskiftet. ${ }^{4}$

I denne teksten skal jeg argumentere for at idéer fra svensk skoletenkning tas opp i norsk sammenheng allerede fra 1850-tallet. Dette påvirker utviklingen av norsk skole fremover mot vedtaket av allmueskoleloven i 1860, samtidig som det påvirker den offentlige debatten om skolen i Norge, og i denne sammenheng forholdet mellom skole og kirke. Artikkelen skal ha to empiriske nedslagsfelt. Den skal for det første skissere relasjonen mellom den den svenske skolemannen Per Adam Siljeström (1815-1892) og hans norske kollega Hartvig Nissen (1815-1874), og argumentere for at Nissen dreier sitt forfatterskap i etterkant av sitt møte med Siljeström i 1854. Siljeström og Nissen hadde i mange henseende sammenfallende karriereveier. Siljeström virket blant annet som lærer og rektor ved Nya Elementarskolan i Stockholm, og ble en viktig offentlig stemme med klare meninger, ikke minst på skolens område. ${ }^{5}$ Han hadde også en rekke posisjoner og verv med politisk innflytelse hva skole og utdanning angikk. Selv om Siljeström spilte en åpenbar rolle for den svenske skolens utvikling i det 19. århundrets siste halvdel, later han til å ha kommet i skyggen av andre skolemenn i tidligere svensk forskning. Han nevnes som regel i utdanningshistoriske oversiktsverk, men har i liten grad vært gjenstand for systematiske studier. ${ }^{6}$ Hartvig Nissen, på sin side, regnes som en av de mest betydningsfulle personer i norsk utdanningshistorie. Dette er ikke minst relatert til rollen han spilte i forbindelse med prosessen som kulminerte i allmueskoleloven i 1860, som lovfestet etableringen av faste skoler over hele landet, og som sikret et fagtilbud som strakk seg utover en opplæring i Luthers katekisme. Den norske idéhistorikeren og sosiologen Rune Slagstad har derfor regnet Hartvig Nissen inn blant de nasjonale strateger; han teller blant dem som har formet det Norge vi kjenner i dag. ${ }^{7}$ Nissen grunnla flere skoler i Christiania på 1840-tallet, og var initiativtaker til og leder av Selskabet for Folkeoplysningens Fremme, som ble stiftet i 1851. Virksomheten i dette selskapet fikk stor betydning for skolens videre utvikling. I likhet med sin svenske kollega hadde han en rekke innflytelsesrike skolepolitiske posisjoner. Han var også en ivrig skribent, både som forfatter av bøker og som bidragsyter i tidsskrifter og aviser. Siljeström og Nissen møtte hverandre første gang under skoleutstillingen i London i 1854, men må nødvendigvis også ha kjent til hverandre også tidligere. Dette kan

3 Johan Backholm, "När lärarna blev nordister: Om Skandinavism och Nordism på de första nordiska skolmöterna," Nordisk Tidsskrift, no. 6 (1994), 17.

4 Ibid.; Hemstad (2008).

5 Se for eksempel Olof Wennås, Striden om latinväldet: Idéer och intressen i svensk skolpolitik under 1800-talet (Stockholm: Almqvist \& Wiksell, 1966), 105.

6 Det grundigste verket på området er Åke Bjerstedt, Självstendighetsmotivet: Ett grundtema i P. A. Siljeströms reformpedagogik (Lund: Uniskol, 1965). I den grad Siljeström har vært gjenstand for grundigere behandling i nyere forskning, er det i vesentlig grad hans bidrag til den svenske skolearkitekturen som har blitt studert. Se Christian Lundahl, "Swedish Education Exhibitions and Aesthetic Governing at World's Fairs in the Late Nineteenth Century," Nordic Journal of Educational History 3, no. 2 (2016), 3-30; Johannes Westberg, Att bygga ett skolväsende: Folkskolans förutsättningar och framväxt 1840-1900 (Lund: Nordic Academic Press, 2015); Cathrine Mellander, Arkitektoniska visioner under statligt förmyndarskap: En studie av Överintendentsämbetets verksamhet och organisation 1818-1917 (Stockholm: Nordiska museets förlag, 2008).

7 Rune Slagstad, De nasjonale strateger (Oslo: Pax, 2001), 50-54. 
blant annet dokumenteres gjennom avisinnlegg som Nissen rykket inn i Morgenbladet i forkant av utstillingen i London. ${ }^{8}$ Siljeströms innflytelse kan spores i flere skrifter fra Nissens hånd. Disse skriftene fikk stor betydning for den norske skolens utvikling frem mot 1860. Likevel har relasjonen mellom Nissen og Siljeström i svært begrenset grad vært gjenstand for studier tidligere. ${ }^{9}$ Når jeg nå skal kaste lys over denne relasjonen, er det først og fremst et av Nissens bidrag i avisen Morgenbladet jeg skal trekke frem. Dette ble trykket sommeren 1855.

For det andre skal jeg se nærmere på hvordan norske skoletidsskrifter brukte materiale fra svensk presse for å danne en opininon som var i overensstemmelse med sin egen profil. Jeg skal her ta for meg tidsskriftene Allmueskoletidende og Den norske folkeskole, som kom ut i Christiania henholdsvis mellom 1861 og 1868 og mellom 1852 og $1869 .{ }^{10}$ De aktuelle tekstene ble trykket i Almueskoletidende og Den norske Folkeskole i løpet av noen uker i 1861. Almueskoletidende og Den norske Folkeskole stod på hver sin side i den polariseringen av den religiøse offentligheten som preget Norge fra midten av det 19. århundre og fremover. Denne polariseringen var blant annet en konsekvens av endringer i det nasjonale lovverket, ikke minst gitt gjennom opphevelsen av konventikkelplakaten (1842) og gjennom dissenterloven (1845). Disse juridiske forandringene gjordet det mulig å danne religiøse frimenigheter, altså forsamlinger utenfor den evangelisk-lutherske kirken. Mange av disse menighetene så det som sin fremste oppgave å hindre at kristendommens budkskap skulle tilpasses verden utenfor. På den annen side så man også en tydeligere grundtvigiansk fløy, der menneskets borgerskap i verden var viktigere enn å forkynne et dogmatisk budskap. Skolen ble en symboltung institusjon for begge leire: Som den viktigste arena for å forme morgendagens borgere ble det tilsvarende viktig å prege den med sin ideologi.

I denne sammenheng skal jeg argumentere for at Almueskoletidende og Den norske Folkeskole bruker de svenske tidsskriftene Wäktaren og Föreningen til å synliggjøre sin ideologiske posisjon. Likt som de norske tidsskriftene inntok en tydelig plass i samtidens kultur- og kirkelandskap, gjorde også de svenske tidsskriftene det samme i sitt hjemland. Rundt midten av det 19. århundre av opplevde Sverige overgripende samfunnsendringer som kunne minne om de norske. På skolens område ble den første folkeskoleloven (Folkskolestadgan) innført i 1842, på kirkens og religonens område ble vekkelsesbevegelsen Evangeliska Fosterlandsstiftningen (EFS) etablert innenfor Svenska Kyrkan i 1856. Dette påvirket den offentlige debatten i Sverige, og måtte nødvendigvis gjøre det - all den tid Sverige - som Norge - hadde århundrelang historikk å vise til hva angikk forholdet mellom kirke og statsmakt. Wäktaren og Föreningen kan ses inn i dette endrede debattklimaet i Sverige. Wäktaren, som kom ut mellom 1853 og 1888, var en riksdekkende utgivelse for den svenske vekkelsesbe-

8 Se Nissens korte tekster i Morgenbladet 11.5 og 23.5 1854, der han oppfordrer norske skolefolk til innsendelse av materiale som han kan ta med til London. Informasjon om utstillingen i London har han fra Stockholmsposten, som han informerer om at han har fått tilsendt fra Siljeström.

9 Relasjonen mellom Siljeström og Nissen behandles overflatisk i Einar Boyesens tobindsbiografi om Hartvig Nissen. Se Einar Boyesen, Hartvig Nissen 1815-1874 og det norske skolevesenets reform (Oslo: Johan Grundt Tanum, 1947), bind 2: Enkeltreformenes tid.

10 Den første årgangen av Almueskoletidende ble utgitt under tittelen Maanedstidende for den norske Almueskole. Tittelen Almueskoletidende vil bli brukt i det følgende, unntatt der hvor det refereres til den første årgangen. 
vegelsen, og hadde sterke bånd til EFS. Den var kjent for å avvise et hvert forsøk på en religiøs legitimering av samfunnsforandringer. Föreningen hadde kommet ut for primært å diskutere den omstridte Torsten Rudenschölds forslag til skolereformer. ${ }^{11}$ Tidsskriftets grunnlegger, Fredrik August Ekström, var ledende i opposisjonen mot Rudenschöld, og la ned et utrettelig arbeid for å forbedre lærernes vilkår så vel som for å styrke og modernisere skolens undervisning. ${ }^{12}$ Wäktaren hadde på sin side vist seg som en av Rudenschölds protagonister. I denne artikkelen skal jeg argumentere for at Almueskoletidende og Den norske Folkeskole leser de svenske tidsskriftene inn i en samtidig norsk polarisering mellom en evangelisk-luthersk offentlighet og en grundtvigiansk folkedanningsoffentlighet, mer enn de forholder seg til de pedagogiske og utdanningspolitiske sidene av debatten.

Med disse to empiriske nedslagsfeltene som utgangspunkt vil det teoretiske grepet i denne artikkelen vil være av stor betydning. Den idéflyt som jeg skal ta for meg skal her ses i lys av såkalte tekstkulturer som blir felles for begge land. Tekstkulturbegrepet har sterke røtter i sosialsemiotikken, og skal, med Johan Tønnessons ord, ses som en gruppe mennesker eller institusjoner som samhandler gjennom tekster ut fra et noenlunde felles normsystem. ${ }^{13}$ Dermed kan også det litterære systemet, for eksempel forlagene, tidsskriftene og avisene, ses som tekstkulturer. De vil til en hver tid ha sine normer og sine konvensjoner som styrer hvordan tekster skal utformes. I denne artikkelen skal etableringen av felles tekstkulturer ses i lys av de muligheter som ble åpnet gjennom en stadig ekspanderende presse. ${ }^{14}$ Både i Norge og Sverige $ø$ kte antallet aviser og tidsskrifter utover i det 19. århundre, og dagspressen og de periodiske skriftene ble viktige for en stadig mer bevisst og kompleks offentlighet. Denne kompleksiteten ble også speilet gjennom et mer omfattende foreningsliv, der fremveksten av religiøse organisasjoner og en økende bevissthet rundt yrkestilhørighet og politisk og sosialt liv kom til syne i aviser og periodika innrettet mot spesielle interessefelt. ${ }^{15}$ Også lærerne ble bevisste sin profesjonelle identitet, og i løpet av århundret tilkom både lærerforeninger og periodika som synliggjorde den viktige plassen denne yrkesgruppen hadde - og har - i samfunnet. ${ }^{16}$ Når jeg nå skal argumentere for at det er tekstkulturene som synliggjør forbindelseslinjene mellom Norge og Sverige på skolens område i denne perioden, er dette relatert til den felles arena som ble etablert gjennom aviser og tidsskrifter på tvers av landegrensene. Gjennom

11 Greven og pedagogen Torsten Rudenschöld utarbeidet en rekke reformplaner for det svenske skolevesenet på 1840- og -50-tallet. Se Gunnar Richardsson, ”Torsten Rudenschöld," Prospects 24, no. 3 (1994), 439-53.

12 "Ännu en skolvetran," Svensk läraretidning: Veckoblad för lärare, upppfostrare och skolvänner no. 22, 18. juni 1891: http://runeberg.org/svlartid/1891/0233.html (lest 28.12.2017).

13 Se Johan Tønnesson, Hva er sakprosa? (Oslo: Universitetsforlaget, 2012), 58-65. Se også Kjell Lars Berges etterord i Johan Tønnesson, red., Den flerstemmige sakprosaen (Oslo: Fagbokforlaget, 2002), $232-41$.

14 Martin Eide, red., Norsk Presses Historie - Bind 1: En samfunnsmakt blir til (Oslo: Universitetsforlaget, 2010), 410. For svensk pressehistorie, se Per Ryden og Karl-Erik Gustavsson, Den svenska pressens historia 2: Åren då allting hände (1830-1897) (Stockholm: Ekerlids förlag, 2000).

15 Tarald Rasmussen og Trygve Wyller, red., Kristelig og borgerlig offentlighet i Norge (Oslo: KULT's skriftserie, 1996).

16 Brit Marie Hovland, For Fedreland og Broderband: Allmugeskolelorarane si møteverksemd $i$ det nasjonale gjenombrotet 1850-1870 (Volda: Norges Forskningsråd, 1999). Se også Gro Hagemann, Skolefolk: Loerernes historie i Norge (Oslo: Ad Notam Gyldendal, 1992). 
pressen ble det skapt felles meningsunivers; nordmenn og svensker leste hverandres aviser og tidsskrifter. Dermed kunne også kunnskapsoverføring så vel som normoverføring og normendring finne sted uten at sender og mottager nødvendigvis var klar over det. I denne artikkelen er det svensk innflytelse på norsk skoletenkning som skal være tematikken.

Det vil dermed være det teoretiske grepet i denne artikkelen som styrer den metodiske innfallsvinkelen. Artikkelens tese, som tar utgangspunkt i etableringen av felles tekstkulturer, skal sannsynliggjøres gjennom empiriske studier av et gitt utvalg tekster. Den metodiske tilnærmingen vil dermed være abduktiv: Tesen skal prøves gjennom empiriske observasjoner, som utgjør grunnlag for sannsynlig ny kunnskap. ${ }^{17}$ Slike teoretiske tilnærminger signaliserer et behov for styrket grad av undersøkelser som angår norsk-svenske relasjoner i unionstiden, også på skolens område. ${ }^{18}$ Forskningen på Norge og Sverige mellom 1814 og 1905 har i stor grad vært dominert av nasjonale fortellinger, der komparative perspektiver har kommet i skyggen av undersøkelser som har tatt for seg landenes nasjonale identitet. Med nye teoretiske grep kan nye historier skrives, og sannsynliggjøre spenninger og forbindelser mellom to land som også i dag er nært forbundet.

Etter denne utvidede innledningen skal jeg ta for meg artikkelens to empiriske nedslagsfelt, før jeg avslutningsvis diskuterer de teoretiske og metodiske implikasjoner av dette arbeidet.

\section{Per Adam Siljeström og Hartvig Nissen}

Siljeström har jeg talt flere ganger med, men kun i Forbigaaende paa Udstillingen. Jeg synes overmaade godt om den Mand, men han har det travelt, og jeg har det travelt, og vi have derfor sagt hverandre, at det fikk gaae et Par Dage, inden vi kunde faae Tid til at stifte ordentlig Bekjendskab. ${ }^{19}$

Det ovenstående sitatet er hentet fra et brev Hartvig Nissen skrev hjem til sin kone, Lena, under oppholdet ved skoleutstillingen i London i 1854. Nissen hadde nå endelig truffet Per Adam Siljeström, som på dette tidspunktet allerede i flere år hadde vært virksom ved Nya elementarskolan i Stockholm. Nya elementarskolan hadde helt siden etableringen i 1828 vært en statlig forsøksskole for utprøving av nye pedagogiske idéer, og skolen hadde hatt - og hadde - en rekke kulturpersonligheter i

17 For gjennomføring av abduktiv tilnærming, se Jan Svennevig, "Abduction as a Methodological Approach to the Study of Spoken Interaction," Norskrift 103 (2001), 1-22.

18 Nyere utdanningshistorisk forskning beveger seg i komparativ retning, og dette gjelder både norske og svenske forskere. Se for eksempel Henrik Edgren, "En främling i den svenska folkskolan: 1870-talets folkskolundervisning i naturkunnighet," og Ruth Hemstad, "Geopolitikk og geografibøker for folket: Den norsk-svenske unionens besværlige beskrivelser," begge i Sann opplysning? Naturvitenskap i nordiske offentligheter gjennom fire århundrer, red. Merethe Roos og Johan Tønnesson (Oslo: Cappelen Damm Akademisk, 2017), hhv. 211-38 og 101-26. Se også to nylig utgitte aviskronikker av Henrik Edgren, Ruth Hemstad og Merethe Roos, "Skolehistorie på kartet," Morgenbladet 27.10.2017 og "Gud og Naturen," Vårt Land 9.12.2017. Et eldre enkeltstående komparativt arbeid av betydning er Anne Helene Høyland Morks hovedfagsoppgave, Unionen i historien: Synet på den svensk-norske union (1814-1905) i svenske og norske loerebøker for folkeskolen i perioden 1860-1920 (Hovedfagsoppgave i historie, Universitetet i Oslo, 2005).

19 Brev fra Hartvig Nissen til Magdalena (Lena) Nissen, 6 juli 1854, Ubehandlet 147, Nasjonalbiblioteket, Oslo. 
sin stab. ${ }^{20}$ Siljeström hadde også markert seg i svensk utdanningsdebatt, blant annet ved å være en ivrig talsmann for kvinners rett til dannelse og utdanning. ${ }^{21}$ Dette hadde også vært en fanesak for Hartvig Nissen, noe man ikke minst så gjennom etableringen av pikeskolen i Christiania i 1849. Siljeström hadde dessuten også gjort det som Nissen var en ivrig tilhenger av: Han hadde reist utenlands for å lære om andre skoler. I 1849-1850 hadde han foretatt en reise til USA, der målet hadde vært å undersøke hvordan undervisningsvesenet ble organisert der. ${ }^{22}$ Nissen hadde også selv vært på en studiereise. I 1851 hadde Stortinget bevilget et reisestipend på 1000 Speciedaler som skulle brukes til studier av skolevesenet i disse landene, for deretter å avgi en beretning som skulle forelegges neste Storting. Året etter hadde stipendiet blitt omdefinert til kun å gjelde Skottland, samtidig som det ble bestemt at det skulle tilfalle Hartvig Nissen. Beretningen fra denne reisen fikk stor betydning for den norske skolens utvikling. ${ }^{23}$ Hva Siljeströms rapport fra Amerika angikk, hadde Nissen da også latt seg begeistre. Siljeströms utgivelse ble gjenstand for en svært positiv anmeldelse fra den norske kollegaens hånd, trykket over to utgaver i Morgenbladet i juni $1852 .{ }^{24}$ Boken var på et slikt nivå at den kunne anbefale seg selv, mente Nissen, og brukte derfor teksten til å la Morgenbladets lesere få innblikk i deler av Siljeströms innledning. Anmeldelsen i den norske avisen ble straks notert i Stockholm, og i Aftonbladet ble det sitert direkte fra nordmannens rosende omtale av sin svenske kollega. ${ }^{25}$

Nissen skulle snart igjen gjøre bruk av Siljeströms arbeider. I Beretning om Christianias almueskolevœesen, utgitt i 1856, tjente Siljeströms skrifter som modell eller

20 Gustaf Sjöberg, Bidrag til Nya elementarskolans historia under de första femti åren af hennes tillvaro 1 1828-1848 (Stockholm: s.n., 1878) og 2 1849-1878 (Stockholm: s.n., 1885).

21 Boyesen (1947), 121.

22 Per Adam Siljeström, Resa i Förenta Statern - första delen: Om bildningsmedlen och bildningen $i$ Förenta Staterna (Stockholm: s.n., 1852), vi.

23 Hartvig Nissen, Beskrivelse over Skotlands Almueskolevosen: Tillligemed Forlsag til forskjellige Foranstaltninger til en videre Udvikling af det norske Almueskolevesen: (en Indberetning i Anledning en af efter offentlig Foranstaltning foretagen Reise) (Christiania: P. T. Mallings Forlag \& Boghandel, 1854). I innledningen til dette skriftet henleder Nissen oppmerksomheten mot utgivelsen av Siljeströms bok: "Sidste Storting bevilgede et Beløp af 1000 Spdlr. til Reisestipendium for en dertil skikket Mand, som i Storbritanien og de nordamerikanske Fristater har at indhente Oplysning om Almueskolevæsenet, og som vil have til Regjeringen at afgive Indberetning, hvilken deretter forelægges næste Storting. Ved naadigst Resolution af 7de April 1852 blev Departementet for Kirke- og Undervisningsvæsenet bemyndiget af hiin Sum at anvænde det Fornødne til Dækkelse af Udgifterne for Departementets Konsulent i Skolevæsenets Anliggender paa en Reise til Skotland [...] Men jeg maa henlede Departementets Opmærksomhed paa, at der senere end Storthingets bevilgning er i Sverige udkommet et Værk over det amerikanske Skolevæsenet af P. A. Siljestrøm. Den Kundskab om Amerikas opblomstrende og i mange henseender blomstrende Skolevæsen, som man før savnede ikke blot hos os, men i hele Europa, er nu skaffet tilveie gjennem dette fuldsændige og omfattende Skrift. At Hr. Siljestrøms værk har en saadan Betydning sees ogsaa deraf, at det allerede er blevet oversat i England. Skulde nu saa kort Tid, efterat Hr. Siljestrøm har skildret de amerikanske Skoleforholde, en Undersøgelse af disse medføre noget klekkeligt Udbytte, da maatte den gaae ind i en Detalj, hvortil der vilde udfordres længre tid og Større Bevilgning, end den, man ialfald nu har at raade over." Nissen (1854a), 1.

24 Hartvig Nissen, "Resa i Förenta Staterna af P. A. Siljeström. Om bildningen i Förenta Staterna. Stockholm 1852. P. A. Norstedt \& Söner. 494 sider," Morgenbladet 11.6.1852 og 13.6.1852.

25 "Norge," Aftonbladet 17.6.1852. I samme avis informeres det om Nissens forestående reise til Skottland. 
referansegrunnlag i to sammenhenger. ${ }^{26}$ For det første i beretningens diskusjon av skolens undervisningsfag, og for det andre i drøftingen av skolens bygninger og inventar. Denne beretningen var et resultat av en konkret bestrebelse på å forbedre den norske skolen. I april 1855 hadde Folkeopplysningsselskapet avholdt et møte der det blant annet ble diskutert hvor vidt den norske skolen var i overensstemmelse med tidens $\mathrm{krav}^{27}$ Siden svaret på dette spørsmålet var negativt, ble det også drøftet hvilke tiltak man skulle sette i verk for å gjøre skolen bedre. Under møtet hadde Eilert Sundt, som hadde vært en av initiativtagerne til selskapet da det ble stiftet, kommet opp med et forslag som var basert på noe han visste hadde fungert i London. ${ }^{28}$ Forslaget gikk ut på å undersøke skolevesenet i Christiania, og især dets forhold til familielivet. Byen kunne deles inn i fire deler, og dertil skikkede menn kunne gå omkring og undersøke saken etter et skjema som var gitt på forhånd, foreslo han. Dette kunne igjen påvirke andre byer og landkommuner til å gjøre det samme. Forslaget ble vedtatt, og undersøkelsene ble gjennomført året etter. Folkeopplysningsmennene fant det hensiktsmessig å dele opp presentasjonen av disse undersøkelsene i to. Den ene delen var den nevnte beretningen fra Christiania Almueskolevæsen, som ble ført i pennen av Hartvig Nissen, den andre delen ble senere publisert som Eilert Sundts velkjente undersøkelse av Christiania-bydelene Pibervigen og Ruseløkken. Rapporten fra almueskolevesenet i Christiania førte raskt til at myndighetene iverksatte konkrete tiltak for å forbedre skolene i byen. ${ }^{29}$

Det er, som Hartvig Nissens biograf Einar Boyesen også påpeker, tydelig at Nissen har hatt kontakt med svenske kolleger under utarbeidelsen av denne beretningen, og det er naturlig å anta at det først og fremst er Siljeström som er hans kontaktpunkt. Nissen viste for det første kjennskap til den nyutgitte rapporten fra almueskolevesenet i Stockholm, som en komité hadde utarbeidet i den svenske hovedstaden. ${ }^{30}$ Lederen for denne komiteen var nettopp Siljeström. I Stockholm, påpekte Nissen i beretningen, hadde en komité i løpet av det siste året foretatt en undersøkelse av almueskolevesenets tilstand og utarbeidet forslag til hvordan man skulle forbedre det. ${ }^{31}$ På bakgrunn av hva som hadde kommet frem av den svenske rapporten, var det klart at det stod langt dårligere til med almueskolene i Christiania enn hva som var tilfelle i Stockholm. Undersøkelsene fra den svenske komitéen hadde vist at et ikke ubetydelig antall barn fikk undervisning i historie og geografi. Enkelte elever fikk også opplæring i naturlære og geometrisk tegning. Dette gikk langt utover fagtilbudet i skolene i den norske hovedstaden, konstanterte Nissen, og det var dessuten grunn til å tro at opplæringen i Stockholmsskolene ville bli enda bedre etter

26 "Beretning om Christianias Almueskolevæsen, udgiven af Selskabet for Folkeoplysningens Fremme," 1ste Tillægshæfte til Folkevennens 5te Aargang (Christiania, 1856).

27 Referatet fra dette møtet er i sin helhet gjengitt i tidsskriftet Folkevennen, som ble utgitt i regi av Selskabet for Folkeoplysningens Fremme. Se "Forhandlinger om Almuskolevæsenet," Folkevennen (1855), 185-220.

28 Se Merethe Roos, Kraften i allmenn dannelse: Skolen som formidler av humaniora. Bidrag til en historisk lesning (Kristiansand: Portal forlag 2016), 80.

29 Boyesen (1947), 250.

30 P. A. Siljeström, "Handlingar rörande ombildningen af folkskoleväsenet i Stockholm," i P. A. Siljeström, Handlingar och skrifter rörende undervisningsväsenet (Stockholm: P. A. Norstedt \& Söner, 1884), 360-530.

31 ”Beretning om Christianias Almueskolevæsen” (1856), 15. 
komiteens rapport. Når det gjaldt skolehusene og skoleinventaret, trakk Nissen igjen frem den svenske rapporten, og pekte på at nesten alt som var anført der passet på de norske forhold, og at det derfor var tjenlig å gjengi den svenske komiteens synspunkter. I den svenske komiteen hadde man dessuten hatt en betydelig autoritet på området, Per Adam Siljeström, som allerede hadde foretatt grundige undersøkelser på dette området. ${ }^{32}$

Siljeström og Nissen har åpenbart hatt en rekke tilknytningspunkter da de møttes første gang i London i 1854, og tilsvarende mye å snakke om. Begge hadde de en åpenbar interesse i samtidig pedagogikk og begge hadde de vært virksomme ved reformpedagogiske skoler. Begge hadde de vært opptatt av kvinners dannelse og begge hadde handlet aktivt for å sette dette på samfunnets agenda. De hadde også begge på et overordnet plan vært opptatt av skolens forbedring. Dette har helt klart vært i tråd med samtidige internasjonale trender, men Siljeström og Nissen har kunnet snakke sammen og forstå hverandre på sine egne morsmål, som representanter for land som politisk sett har vært nært forbundet. De har også hatt godt kjennskap til hverandres virke fra før. Dette har trolig gitt grunnlag for et vennskap som har vart livet ut. Ettertiden har i liten grad brevveksling eller annen form for dokumentasjon tilgjengelig som kan bevitne en kontakt mellom Siljeström og Nissen i årene som fulgte. Blant noen få brev som tematiserer relasjonen mellom de finnes det imidlertid ett fra Siljeströms hånd, stilet til Hartvig Nissens sønn Per Nissen umiddelbart etter Hartvig Nissens død i 1874. I dette brevet takker Siljeström Nissen for et 20-årig langt vennskap, og understreker hva Per Nissens far har betydd for ham. ${ }^{33}$ Brevets dateringer gjør at det grunn til å tro at dette dreier seg om mer enn høflighetsfraser: det gikk fem dager fra Nissen døde til Siljeströms brev var på vei tilbake i retning Christiania. ${ }^{34}$ Det later dermed til å ha vært viktig for Per Nissen å fortelle Siljeström at Hartvig Nissen var død, likeens som det har vært viktig for Siljeström å uttrykke sin medfølelse tilbake.

Gitt disse forutsetningene blir det enda viktigere å spørre: Hva kan Siljeström og Nissen ha snakket om i London som ikke kan dokumenteres i materiale som er kjent for oss i dag? Kan de ha hatt kontakt med hverandre gjennom brev som er gått tapt for ettertiden? Hva har de lest av hverandres litteratur? Hva står i tekstene de skriver? Den teoretiske tilnærmingen i denne artikkelen gjør de tekstene de har produsert til autonome studieobjekter. Jeg skal derfor ta for meg en interessant dreining i Nissens forfatterskap, som skjer i etterkant av møtet med Siljeström i London. Dreiningen handler om noe som blir et overgripende tema i skole- og utdanningsdebatten fra midten av det 19. århundre; verdsliggjøring av skolen. I tekster som ble utgitt tidlig på 1850-tallet tok Hartvig Nissen klart til orde for at de bånd som var og hadde vært

32 Samme år (1856) hadde Siljeström publisert tekstene Inledning til skolarkitekturen og Bidrag til skolarkitekturen: Ritningar och beskrifningar öfver skolhus, skolmöbler, undervisningsmedel m. $m$., til tjenst for skolstyrelser, skolföreståndare, lärare och andre för undervisningsväsenet interesserade personer. Det er disse publikasjonene Nissen her henviser til. Se også over, note 5.

33 Brev fra Per Adam Siljeström til Per Nissen, 9. februar 1874. Ubehandlet 147, Nasjonalbiblioteket, Oslo.

34 Hartvig Nissen døde 4. februar 1874. Det fremgår av brevet at Per Nissen har skrevet til Siljeström allerede to dager etter, altså 6. februar. Brevet er så sendt til Stockholm, og Siljeström daterer sitt svar 9. februar. 
mellom kirken og skolen, måtte vedvare fremover. ${ }^{35}$ I Beskrivelse over Skotlands Almueskolevoesen blir dette knyttet til skolens rolle som oppdrager. ${ }^{36}$ Skolen skulle oppdra både for det borgerlige og det kirkelige liv, og den stod i en inderlig relasjon til både stat og kirke, understreket Nissen. Disse relasjonene var forankret juridisk, og skolens religionsundervisning måtte derfor være av konfesjonell karakter. Men det var feil å si at skolen var en religionsskole, all den tid dissenterloven fritok dissentere fra å sende barna sine til skolens religionsundervisning, fortsatte han. Dissenterne ville imidlertid miste noe vesentlig: Tro og lærdom hang på det nærmeste sammen, påpekte han, det i sakens natur. For slik som Herren selv fremtrådte som lærer for disiplene og sendte de ut for å undervise alt folk, fordret skolen tro i den forstand at den krevde at eleven hadde tillit til lærerens ord. "Hvorledes skulde det da kunne være Skolen fremmed ogsaa at kræve Tillid til den guddommelige Lærers Ord og gjennem Ordet om ham og Ordet fra ham lære dem at fatte de høieste Sandheder?", spør han. ${ }^{37} \mathrm{I}$ lys av skolens tilknytning til kirken og det offentlige, så vel som kristendommens undervisningspregede karakter, ble presten og læreren dermed tilkjent beslektede roller: de stod begge i et gjensidig avhengighetsforhold til kirke og stat. Det synes altså å være maktpåliggende for Nissen å understreke den norske skolens konfesjonelle karakter, like fullt som det var maktpåliggende å understreke at staten i juridisk forstand var bundet av den evangelisk-luthersk konfesjonelle kirken. Denne argumentasjonen finner vi også igjen når Nissen ytrer seg i pressen, i polemikk mot meningsmotstandere og debattanter han mente hadde misforstått hans budskap. ${ }^{38}$

Imidlertid skjedde det en aksentforskyvning i Nissens tekster rundt midten av 1850-tallet som i denne sammenheng er av betydning. I artikkelen "Om Skolens navnlig Almueskolens Forhold til Livet og om Tidens, i dette Forhold begrunnede, Krav til vor Almueskole", trykket i Morgenbladet 8.6.1855, kom Nissen blant annet inn på de fordringer som kunne stilles til skolens religionsundervisning. Når det ble spurt etter hvor vidt den opplysning som skolen meddeler allmuen var i overensstemmelse med tidens krav, måtte man ta hensyn til både det forråd av innsikt som folket var i besittelse av, så vel som det livet de levde, påpekte han. Særlig skulle man merke seg at det religiøse liv potensielt inneholdt et større register av forestillinger enn hva det gjorde før. Dette ville samtidig også gjøre kirkens lære potensielt

35 Nissens klare konfesjonelle forankring blir også tatt frem i senere debatter. I forbindelse med striden rundt P. A. Jensens lesebok på 1860-tallet, er blant annet teologen Julius Bruun nøye med å påpeke at det aldri var Nissens intensjon å sidestille undervisningen i kristendom med annen undervisning, da Nissen argumenterte for bredere undervisning i første halvdel av 1850-tallet. Dette bruker Bruun som et argument for rettmessigheten av den nye leseboken, og for å vise at den nye leseboken ikke er uforenlig med kristen tro, slik enkelte av kritikerne hevdet. Se Julius Bruun, "Nogle Bemerkninger aangaaende den nye Læsebog for Folkeskolen og Folkehjemmet," Luthersk Kirketidende 8 (1867), 129-48, 241-47, 354-64, 385-97. Se også Merethe Roos, ”Nogle Bemerkninger aangaaende den nye Læsebog for Folkeskolen og Folkehjemmet: En nylesning av Julius Bruuns tekst i Luthersk Kirketidende 1867," Norsk Pedagogisk Tidsskrift 2 (2018), under utgivelse.

36 Nissen redegjør spesielt for teksten mellom kirke, skole og stat i denne tekstens bilag A, som følger etter den ordinære gjennomgangen av skolevesenet i Skottland og forslagene til hvordan det norske skolevesenet kan utvikles.

37 Nissen (1854a), 473.

38 Se for eksempel disputten med prost Halvor Folkestad i Morgenbladet 1853 og 1854, blant annet Nissens artikkel "Hr. Provst Folkestad om Almueskolens Administrationsforholde og om dens Forhold til kirke og Stat," Morgenbladet 4.8.1853 og Folkestads artikkel "Hr. H. Nissen i forhold til Almueskolesagen," Morgenbladet 16.4.1854. 
mer utsatt for kritikk. Mens angrepene mot religionen tidligere nesten alltid hadde kommet fra vantroens standpunkt, hadde dissenterloven åpnet for rettmessigheten av ulike trosuttrykk. Dermed var det nå fritt frem for å angripe den evangelisk-lutherske lære. "Mod dette slags Angreb hjælper det kun lidet, at man har udviklede og klare dogmatiske Begreber", argumenterte han. ${ }^{39}$ For å verne religionen var det om å gjøre å løsrive den fra dogmene, det som det kom an på, var "Følelsens Inderlighed og Troens Styrke”. Imidlertid var det ikke lenger tilstrekkelig å sørge for å utvikle en varm religiøs følelse og en barnlig tillitsfull tro til de viktigste kristne trossannheter. Siden allmuemannen nå hadde rundt seg et stort mangfold av religiøse tanker som forsøkte å påberope seg overensstemmelse med Skriften, "ja, endog hører Mormonerne hente Vidnesbyrdet for sine Vildfarelser fra Guds eget ord”, måtte han besitte en større klarhet i de religiøse begreper. ${ }^{40}$ Samtidig måtte han ha mer kjennskap til Bibelen og utlegningen av dens viktigste skrifter. Dette kan kun skje gjennom meddelelse av et allsidig undervisningsstoff, "hvis Tilegnelse medfører Øvelse og Skjærpelse først for Anskuelsesevnen og saa for Indbildningskraften og dernest for Forstanden og mere specielt for Begrepsevnen”. Dette gjør at man måtte flytte fokus fra religionens begreper og over på religionens innhold: de kristne trossannheter måtte meddeles gjennom å legge ut kristendommens historiske åpenbaringer, og ikke lærebegrepet.

Det ser dermed ut til at Hartvig Nissen foretar en forskyvning fra det eksplisitt konfesjonelle og over til at det konfesjonelle i stor grad tas for gitt. Slik det formidles i teksten fra Morgenbladet, er skolens evangelisk-lutherske forankring ikke lengre uttrykkeliggjort, nå ligger vekten i større grad på det eksistensielt religiøse. Det er imidlertid ingen tvil om at det eksistensielt religiøse tenkes innenfor rammene av evangelisk-luthersk tro, men denne synes imidlertid å være skjøvet i bakgrunnen eller nedtonet til fordel for religionens inderlige aspekt. Der Nissen tidligere først og fremst hadde understreket skolens konfesjonelle forankring, var det nå et eksistensiet aspekt som stod i sentrum. Det viktigste var ikke lenger lærebegrepet, altså dogmene, men essensen av kristendommens budskap.

I denne sammenheng er det interessant at denne aksentforskyvningen skjedde etter at Nissen hadde møtt Per Adam Siljeström i London. Siljeström var på dette tidspunktet engasjert i å gi ut tidsskriftet Dagens Häfder (1853-1854), der han nesten uten assistanse fra noen andre publiserte sine tanker om skole og opplysning. Dette gjaldt ikke minst spørsmålet om hva religionsundervisning skulle være. Skolens religionsundervisning måtte være fristilt fra dogmatikk, hevdet han. ”Nog vet man, att teologiska systemer och lärda framställningar i dogmatiken kunna uttänjas snart sagd i oändlighet, och nog vet man äfven, att den dogmatiska lärobok som för närvarande begagnas vid folkundervisningen, intager ett altför synbart rum på schemat; men til hva båtnad för den kristliga religiositeten, er en annan fråga." ${ }^{41}$ I stedet

39 Hartvig Nissen, "Om Skolens, navlig Almueskolens Forhold til Livet og om Tidens, i dette Forhold begrunnede, Krav til vor Almueskole," Morgenbladet 8.6.1855.

40 Mormonerne ble sett som en alvorlig samfunnstrussel, blant annet fordi de stod for en teologi som virket fremmed i forhold til det norske samfunnet. Se Frode Ulvund, "Travelling Images and Projected Representations: Perceptions of Mormonism in Norway 1840-1860," Scandiavian Journal of History 41, no. 2 (2016), 208.

41 "Folkbildningen - Om religionsundervisningen," Dagens Häfder, 2. Januari 1854. Alle artikler under overskriften "Folkbildningen" er markert med fotnoten "Stående rubrik - Meddel. af P. A. Siljeström". 
måtte religionsundervisningen orienteres mot religionens indre vesen. "Vi måste hafva bort utanläsningen, och i stället få någon lefvande religionskunskap; vi måste hafva bort denne kristendom på tungan, och i stället få nogon Kristendom ned til hjertat." ${ }^{42}$ Denne nyorienteringen innebar blant annet at de som ble ansett for å være best skikket til å drive god religionsundervisning ikke nødvendigvis var de utdannede religionslærerne eller de som var utdannet prester. Derimot var det de som Siljeström kaller "de virkelige religiøse mennesker", det vil si de som åndens kraft har fătt virke i. Dette kan være enten prester, religionslærere eller andre medborgere, påpekte han i tidsskriftet. Dette hadde sammenheng med religionens karakter. Kristendommen var ikke en "lexa, en slentrian, ett menskligt kunnskapskram, utan lefvande Guds ord", og den som formidlet dens budskap, kunne ikke formidle noe tillært, men måtte formidle noe som mennesket selv hadde opplevd.

Imidlertid var det ikke slik at Siljeström mente at religionsundervisningen skulle tas ut av skolen. Tvert imot, det handlet om å lede elevene til "förtrolighet med och kärlek för bibelordet", altså å gjøre de sikrere på hva som står i Skriften. Opplæringen i Bibelens innhold måtte imidlertid foregå på en slik måte at de så relevansen for eget liv, og det kunne ikke skje gjennom "utanläsning af katekesen". Dermed forenes Nissen og Siljeström i forståelsen av hva som var kristendommens hovedanliggende, og hvordan kristendommen fikk betydning i menneskers liv. Det dreiet seg om å la Bibelen tale i kraft av sitt budskap, heller enn sine dogmer.

Som jeg viste tidligere, bør det ikke være tvil om at Siljeström og hans tekster har hatt betydning for utviklingen av den norske skolen på 1850-tallet. Siljeströms idéer blir tatt opp i norsk offentlig ordskifte etter publikasjonen av rapporten fra studiereisen til Amerika, likeledes som de også blir brukt i tekster som fikk betydning for forbedring av skolen i den norske hovedstaden. Det interessante i denne sammenheng er imidlertid hvordan pressen, avisene og tidsskriftene, bandt Norge og Sverige sammen. Både Siljeström og Nissen brukte nyhetsmediene for å uttrykke hva religion skal være. Felles for de var en forståelse av at religionen skulle angå det levde liv, heller enn kjennskap til dogmer og læresetninger. Dette betydde ikke for noen av de at bibelkunnskapen skulle settes til side, heller fordret det utvidet kunnskap om Bibelen og Bibelens viktigste skrifter. Men denne kunnskapen måtte aktualiseres for hvert enkelt menneske. For Nissens vedkommende innebar dette en forskyvning av hvordan han fremstilte hva religion skulle være, slik det kom til uttrykk i teksten fra Morgenbladet. Fra eksplisitt å være forankret i en evangelisk-luthersk lære, ble det nå til noe som i større grad var betinget av et eksistensielt aspekt. Om denne forskyvningen skyldtes samtaler mellom Siljeström og Nissen, vet vi ikke. Her kan vi bare konstantere at ytringer i pressen, i aviser og tidsskrifter, bandt Norge og Sverige sammen, og skapte en felles tekstkultur. Vi kan også konstantere at dette skjer etter at Nissen hadde møtt Siljeström i London. I norsk sammenheng er dette uansett et forsiktig skritt i retning av den kampen for skolens løsrivelse fra kirken som skulle prege kulturlandskapet i de kommende tiårene. Denne kampen kom også til uttrykk i tidsskriftene Den norske Folkeskole og Almueskoletidende, som jeg i det følgende skal se nærmere på. I disse tidsskriftene blir svenske trykte medier brukt til å skape tekstkulturer som står rakt mot hverandre.

42 "Folkbildningen - Om religionsundervisningen," Dagens Häfder, 1. Oktober 1853. 


\section{Almueskoletidende og Den norske Folkeskole, Föreningen og Wäktaren}

Da Almueskoletidendes første redaktør, læreren Samson Madsen Krogness, tok på seg oppgaven med å utgi dette tidsskriftet, hadde han allerede en viss skribenterfaring. Tidligere hadde han publisert både en andakts- og salmebok. ${ }^{43}$ Det var redaktøren for Norsk Kirketidende, Theodor Christian Bernhoft, som en del år tidligere hadde grunnlagt Israelsmisjonen i Stavanger, som hadde oppfordret Krogness til å utgi et skoleblad. Almueskoletidende hadde dermed utspring i et miljø der man gikk inn for å bevare - og helst også styrke - skolens luthersk-konfesjonelle forankring. Tidsskriftet opphørte i 1868, men Norsk Skoletidende, som ble utgitt fra samme år med Nils Egede Hertzberg som redaktør, fortsatte i samme spor som Almueskoletidende. Stortingsmannen og høyrepolitikeren Hertzberg hadde stor politisk innflytelse, og gjennom tallrike skrifter og offentlige debattinnlegg kjempet han i første linje mot alle former for verdsliggjøring av samfunnet. ${ }^{44}$ Både Almueskoletidende og Norsk Skoletidende kan dermed regnes som formidlingsarenaer for den verdikonservative og religiøse høyresiden i samtidens Norge.

I forordet til tidsskriftets første utgave gjorde Krogness det klart hva magasinet som lesereren nå gir seg i kast med skulle være. ${ }^{45}$ Han innledet med å avgense sin publikasjon fra Den norske Folkeskole. Der bladet Den norske Folkeskole primært tok mål av seg til å være et rent skoleblad i den forstand at det beskjeftiget seg med skolens utvikling som skole og skolens forbindelse med hjemmet, ønsket Almueskoletidende å være et tidsskrift som belyste skolens kirkelige stilling. Det ble raskt klart at tidsskriftet hadde skolens evangelisk-kristelige karakter som sin viktigste sak, og at dets oppgave var å minne de foresatte og skolelærerne hvilket fundament skolen stod på. Fra denne stadfestingen av tidsskriftets oppgave, gikk Krogness over til å gjøre rede for tidsskriftets karakter. Han understreket hvordan Kristus måtte være sentrum for all undervisning, hvordan Kristi fremferd måtte være en hver lærers fremste eksempel og hvordan Kristus kunne og skulle være kilden til menneskets kunnskap, forstand, visdom og kraft. Samtidig brukte han innledningen til å markere side i aktuell samtidig debatt: Ved å omskrive tittelen på en av Grundtvigs utgivelser tok han avstand fra Grundtvigs tanker samtidig som at han understreket den tette forbindelsen mellom skolen og kristendommens trosinnhold: "Skolen er virkelig en Skolesag!", proklamerte han, og som sådan "staar den i et bestemt tjenende Forhold til Kirken". ${ }^{46}$ Dermed skulle kirken og troen være ledesnor for undervisningen, $\mathrm{i}$ den forstand at skolens virksomhet fullstendig var betinget av Bibel og bekjennelse. Skolens kristne oppdragermandat var også overordnet en hver form for borgerlig opplysning, liksom også staten var forpliktet til å tilse at kirkens budskap styrte skolens undervisning. All den tid staten hvilte på lovens grunn, og loven var

43 Jørund Midttun, "For leg og lærd: En oversikt over norske kristelige tidsskrifter 1800-1895," i Kristelig og borgerlig offentlighet $i$ Norge, red. Tarald Rasmussen og Trygve Wyller (Oslo: Norges Forskningsråd, 1996), 24.

44 Merethe Roos, "Å velte en kjempe: Tekstkulturer og modellesere i Nils E. Hertzbergs skrifter," Sakprosa 8, no. 2 (2016).

45 Samson M. Krogness, "Et Ord forud," Maanedstidende for den norske Almueskole, no. 1 (1861), 2-7.

46 Krogness henspeiler her på Grundtvigs skrift "Er troen virkelig en Skolesag" fra 1836, der Grundtvig lakonisk hevder at troen overhodet ikke er noen skolesak, og at den religionsundervisning som vi i århundrer hadde plaget oss selv med, var en villfarelse. Se N. F. S. Grundtvig, ”Er troen virkelig en Skolesag?" http://grundtvigcenteret.au.dk/fileadmin/www.grundtvigcenteret.au.dk/digitalisering/s_g_i_grundtvigs_skrifter/skolesag.pdf (lest 30.1.2017). 
tuftet på den evangelisk-lutherske kirken, sa det seg selv at staten måtte kontrollere at kirken øvet den største innflytelse på skolen.

Den norske Folkeskole tilhørte på sin side den fløyen i det kulturelle, politiske og kirkelige landskap som Almueskoletidende forsøkte å avgrense seg fra. Skolebladet var opplysningsorientert, og bladets redaktør var identisk med redaktøren for Folkevennen, Ole Vig. Folkevennen hadde blitt etablert i 1852, som folkeopplysningsselskapets tidsskrift. I redaksjonell forstand stod imidlertid Vig friere i skoletidsskriftet enn hva han gjorde i Folkevennen, og han kunne dermed blant annet la grundtvigianske sympatier få fritt spillerom. Etter Vigs død i 1857 ble det redaksjonelle ansvaret overtatt av Gerhard Bergh og Andreas Martinus Feragen, som redigerte skriftet frem til 1868. Bergh og Feragen fortsatte samme linje som Vig i utgangspunktet hadde lagt opp til, og publikasjonen hadde dermed også fremover et grundvigiansk preg.

Forordet i tidsskriftets første utgave gir bilde av en ganske annen publikasjon enn den Samson Krogness skulle utgi noen år senere. ${ }^{47} \mathrm{I}$ Den norske Folkeskole står opplysningen sentralt, og mennesket ble skjøvet i sentrum på en måte som var karakteristisk for grundtvigiansk tenkning. Det blir også klart at menneskets opplysnings skjedde i samspill med andre, i den forstand at det var en dialektisk og kontinuerlig prosess: "Det er aldeles vist, at kun igjennem ærlig aandelig Kamp vil Sandheden findes og seire. Det nytter ikke, at man vil beholde sine Meninger for sig selv, og søge at dræbe Andres ved at tie til dem; man faar virkelig udtale sig, hvis man alvorlig vil fremme det Gode". ${ }^{48}$ Senere i den innledende teksten blir det enda mer tydelig hvordan utgiveren av dette tidsskriftet tenkte prinsipielt forskjellig fra utgiveren av Almueskoletidende. Det var ikke skolen og kirken som hørte sammen, men derimot skolen og hjemmet. Likeens var hovedformålet med å gjøre rede for hva opplysning var, ikke knyttet til å forklare opplysningens underordning i forhold til den kristne tro, men derimot til å bringe opplysning til et så bredt lag av folket som mulig. Hvordan Vigs tidsskrift skilte seg fra Almueskoletidende blir ikke minst tydelig ved å sette innledningstekstenes avsluttende avsnitt opp mot hverandre. Der Vig uten henvisning til noe annet enn et håp om at de skal klare å vekke "Sandsen for den levende Oplysning og rense Begrepene derom", la Samson Krogness utgivelsen av tidsskriftet i Guds hender: "Sagen selv og dette Blad være nu Herren anbefalet. Han give Naade til, at ogsaa dette Foretagende maa ske til hans Ære og Menighedens Gavn" ${ }^{49}$

Som Almueskoletidende etter hvert ble viktig for den samtidige konservative religiøse fraksjon av norske lærere, hadde også Den norske Folkeskole stor betydning i forhold til etableringen av en grundtvigiansk opinon fra 1850-tallet og fremover. Mye av dette var Ole Vigs fortjeneste. Vig nøt allerede i utgangspunktet høy grad av tillit blant landets lærere, ikke minst som en konsekvens av det arbeidet han hadde lagt ned for å danne lokale lærerforeninger før han flyttet til Christiania. ${ }^{50}$ Vig, som blant annet hadde virket som lærer i Kristiansund før han kom til hovedstaden for å være redaktør for Folkevennen, hadde ivrig stått i spissen for å organisere lærerne

47 Ole Vig, "Forord," Den norske Folkeskole: Et Maanedsskrift for Lorere og andre Opdragere (1852), $1-5$.

48 Ibid.

49 Krogness (1861), 7.

50 Hans Jørgen Dokka, Fra Almueskole til Folkeskole: Studier $i$ den norske folkeskoles historie i det 19. århundre (Oslo: Universitetsforlaget 1967), 117. 
som gruppe i den norske vestlandsbyen. Når Vig nå kom ut med et rent skoletidsskrift, skulle det samle de grundtvigianske lærerne enda mer tydelig som gruppe, og bidra til å danne en motvekt til de lærerne som var mer pietistisk innstilt. ${ }^{51}$ Som interessetidsskrift for lærerstanden tegner dermed Almueskoletidende og Den norske Folkeskole representative bilder av deler av norsk offentlighet på 1860-tallet, og utgivelsene viser hvordan lærerne samler seg i grupper som står steilt mot hverandre.

Jeg skal så vise hvordan Wäktaren og Föreningen ble brukt i de norske tidsskriftene for å etablere tekstkulturer som gikk på tvers av grensene mellom Norge og Sverige. Tematiseringen av de svenske publikasjonene ble innledet av en artikkel i Almueskoletidendes andre utgave i $1861 .{ }^{52}$ I en notis merket Kristiania 4. januar henviste skribenten til en artikkel trykket i Wäktaren, der den svenske avisen hadde omtalt subskripsjonsinnbydelsen til det norske skolebladet han selv skrev i. Teksten i Wäktaren hadde tittelen "Om behovet af en god Tidning för Folkskolan", og er trykket i avisens utgave nr. 51 (1859). ${ }^{53}$ Artikkelen i Almueskoletidende gjenga en norsk oversettelse av deler av teksten i den svenske utgivelsen, og i innledningen til teksten til Almueskoletidende kan man lese følgende:

\begin{abstract}
Wäktaren, en "Tidning för Stat och Kyrka", der udgives i Stockholm, har nylig i en Opsats "Om behofwet af en god Tidning för Folkskolan" gjengivet vor Subskriptionsinbydelse paa denne Skoletidende, og knyttet dertil bl.a. følgende Udtalelse: "Det har været os en stor Tilfredsstillelse at læse denne Anmeldelse, fordi den synes at vidne om, at man i Norge har rettelig opfattet Endemaalet med en Almueskoletidende og dersom dette Foretagende udføres i den rette Aand og paa den rette maade, kan det blive til stort Gavn og burde derfor opmuntre til Efterfølgelse i Sverige. Vi har nemlig længe følt Trangen til en saadan Tidende hos os, og forgjæves ventet, at denne Trang skulde bli tilfredsstillet. Men da det nu ei er Skeet, kunne vi ei undlade at benytte den Anledning, som det norske Foretagende give os, til at opmuntre indsigtsfulde og for Folkets opdragelse nidkjære Mænd at sætte denne uudsigelige vigtige Sag i Gang. Vi kunne navnlig for vor Del ikke anse Mangelen afhjulpen ved det "Tidsskrift för Folkskolans och Kyrkomusikens wänner" som under Navn af "Föreningen" nu i 4 aar har været udgivet. ${ }^{54}$
\end{abstract}

Skribenten gjorde imidlertid et retorisk grep som i denne sammenheng ikke er uten betydning. Almueskoletidendes exordium starter i annet avsnitt i det som opprinnelig er Wäktarens tekst. Dermed blir lesernes oppmerksomhet rettet mot noe annet enn hva det gjør i avisen de siterte fra. I Wäktarens første avsnitt presenterte skribenten det planlagte norske skriftets utgivere, skribenter og ulike teksttyper, før han avslutningsvis fastslo hvordan den norske publikasjonen hvilte på Guds ord: "Utgifwaren förklarar sig wilja ställa sitt Blad på Guds ords och wåra bekännelsesskrifters grund, och nedställar Herrans nåd och wälsignelse öfwer sitt företag, att det måtte blifwa till Hans ära och församlingens gagn". ${ }^{55}$ Dermed ser vi at Wäktaren brukte den i retorisk

51 Vigs blad vakte umiddelbar interesse, og i en artikkel i tidsskriftets annen utgave fremgår det at bladet fikk 400 abonnenter i løpet av det første året det eksisterte. Ibid.

52 "Skole-Efterretninger," Almueskoletidende, no. 2 (1862), 29-30.

53 "Om Behofwet af en god tidning för Folkskolan," Wäktaren, no. 51 (1859), upaginert.

54 "Skole-Efterretninger," no. 2 (1862), 29.

55 "Om Behofwet af en god tidning för Folkskolan" (1859). 
forstand viktige innledningen til å dra lesernes oppmerksomhet mot at det planlagte norske skriftet var tuftet på Guds ord. Almueskoletidende, derimot, brukte innledningen til å fastslå at man i Sverige ikke hadde et formålstjenlig skoletidsskrift, og at Tidsskrift för Folkskolans och Kyrkomusikens wänner (Föreningen) ikke tilfredsstilte de kravene som måtte stilles til et slikt skrift.

Den negative oppmerksomheten omkring Föreningen som blir etablert i Almueskoletidendes exordium, blir forsterket i tekstens videre forløp. Artikkelforfatteren fortsatte med å gjengi deler av teksten fra Wäktaren, og å bruke tekstdeler som rettet oppmerksomheten mot at Föreningen ikke kunne ses som et adekvat tidsskrift for skolen. ${ }^{56}$ Artikkelen som opprinnelig er trykket i Wäktaren var også vesentlig lengre enn den teksten som ble gjengitt i Almueskoletidende, og hadde et adskillig mer diskuterende preg enn teksten i det norske skriftet. I Wäktaren ble det diskutert utførlig hvorfor ikke Föreningen holdt mål som et tidsskrift for skolen, både hvordan det tok feil i spørsmålet om Rudenschölds skoleplaner så vel som hvordan det ikke var tuftet på det rette kristne fundament. ${ }^{57}$ Ved at Almueskoletidende brukte et tekstutdrag hvor en negativ omtale av Föreningen var dominerende, og ved at det ikke ble gitt noen forklaring på hvorfor Föreningen ble omtalt negativt, ble det norske tidsskriftets lesere påvirket til å gjøre seg opp en mening om to svenske tidsskrifter som de antageligvis ikke visste så mye om enda.

Slikt kan provosere meningsmotstandere, og hvordan dette kan oppfattes av leserne som et forsvar for Wäktaren, så vel som et forsøk på å skape negativ oppmerksomhet rundt Föreningen, blir klart ut fra den reaksjonen som snart trykkes i Den norske Folkeskole. I en polemisk notis som ble publisert i tidsskriftets nr. 18 belyste Gerhard Bergh de svenske skoleforhold i form av en anmeldelse av Föreningen. ${ }^{58}$ Bergh gjorde hva han kunne for å skape en opinion blant sine lesere: Föreningen var den eneste periodiske publikasjonen som behandlet det lavere skolevesenets forhold i Sverige, påpekte han, de leverte to nummere hver måned, og tidsskriftet kunne lett tinges ved et hvilket som helst norsk postkontor. Teksten svarte indirekte på den positive omtale som ble Wäktaren til del i Almueskoletidende gjennom å presentere en tilsvarende positiv omtale av Föreningen:

Tidsskriftet fortjener Opmærksomhed og kræver Agtelse ogsaa hos vore Skolevenner for den Dygtighed, hvormed det redigeres, saavelsom for den Fremgang, hvormed det virker. Dersom Iver for Folkeoplysning, Nidkjærhed for Skolens Fremgang og Lyst til at virke tilbedste for en kristeligsindet Lærerstand i Forening med Retsind

56 "Om derimod en Tidende mere udelukkende taler Skolelærernes personlige Sag (at de maa vinde 'Agtelse og Brød' som det hedder i 'Föreningens' Program), saa kommer man snart til at lade det Væsentligste af Sigte og uddanne et Embetslaug, hvis særskilte Interesse først og fremst paasees. Skal derfor en Tidende med Held og Fremgang kunne arbeide for Opnaaelsen af begge disse Formaal, saa synes det nødvendigt, at Redaktionen, saaledes som den norske, understøttes, ikke alene af Almueskolelærere, men ogsaa af Mænd med høiere, grundigere og alsidigere Dannelse. 'Föreningen', som udgives af en Almueskolelærer, har ikke fattet sin Opgave fra et saadant mere omfattende og ophøiet Standpunkt. Den staar desuden ikke, som den norske Tidende, klart og bestemt lover, paa 'Guds ords og vore Bekjendelsesskrifters Grund"' "Skole-Efterretninger" (1862), 30.

57 Den svenske teksten er trykket over tre hele spalter i kvartformat, mens den norske gjengivelsen har fire avsnitt i oktavformat.

58 Teksten, som er trykket under fanen "Boganmeldelser," har tittelen "Föreningen. Tidsskrift för Folkskolans och Kyrkomusikens Vänner. Adr. Köping i Sverige," Den norske Folkeskole, nr. 18 (1862), 284-86. 
i Grundsætninger, Maadehold i Omdømmet og Forstand paa Skolens Krav og Tarv danne Grundbetingelserne hos den Mand, der med sundt Gavn kan forstaa Udgivelsen af et saadant Skrift, da maa Skolelærer Ekstrøm ansees som særdeles velskikket for det alvorlige Hverv, han har paataget sig og snart i 5 Aar forestaaet. ${ }^{59}$

Her blir det også klart at det dreiet seg om en konflikt mellom de to svenske publikasjonene. Almueskolens tilstand i Sverige synes å være omtrent tilsvarende tilstanden i Norge, forklarte Bergh. I etterkant av den svenske skoleloven i 1842 hadde man imidlertid sett klare fors $ø \mathrm{k}$ på å trenere den forbedringen av skolen som denne loven innebar. Påskuddet for å gjøre dette synes å ha vært at almueskolens barn kun trengte det absolutte lavmål av undervisning. Mot disse destruktive trendene hadde Föreningen vist seg som det godes forkjemper: Avisen hadde opptrådt "baade kjækt, grundigt og med stort Held. Paa samme tid har det maattet føre en alvorlig Kamp mot det Piesteri, som hist og her vil trænge sig ind med daglange Andagtsøvelser i Skolen, med Børneplageri, med Mistro til Folkedannelsen og med aabenbar Ringeagt for alsags verdslig Oplysning, og som har fundet ivrigt Medhold ogsaa i 'Wäktaren." ${ }^{30}$ Med dårlig skjult bruk av ironi antydet han at utgiveren av Almueskoletidende helt sikkert ikke hadde kjent til hvilken respekt Föreningen nøt blant lærere i sitt hjemland, ettersom han har satt det svenske skoletidsskriftet i et så dårlig lys som det han har gjort i nr. 2. Siden Föreningen var så viktig i svensk sammenheng, skulle Den norske Folkeskole trykke verdifulle tekster fra dette tidsskriftet i tiden fremover, avsluttet Bergh sin anmeldelse.

Den ironiske tonen ble i høyeste grad oppfattet av Almueskoletidenes redaktør. I et utdypende svar til Gerhard Bergh i Almueskoletidendes utgave 10/1861 fortsatte Krogness sitt forsvar for Wäktaren, og synliggjorde for leseren hvordan denne avisen var noe helt annet enn det Bergh har villet fremstille den som. ${ }^{61}$ Tonen er påtatt høflig, slik at irritasjonen fremstår som tydelig for en som leser teksten i ettertid. Krogness innledet teksten med å beklage seg over Berghs fremgangsmåte, som han åpenbart fant provoserende. Videre gjorde han det klart for leseren at han anså det som var presentert for å være Berghs private syn, og ikke Den norske Folkeskoles, siden Berghs medredaktør ikke hadde undertegnet teksten. Krogness anmodet også Bergh om å holde seg til saken og å unngå konflikt, slik som dette også kunne vært unngått fra deres side:

Det forekommer os nemlig, at Hr. Bergh meget vel kunde have anbefalet og rost "Föreningen", om han havde ladet vor Ytring blive Staaende for sin egen Regning ulastet. Vi indføre f. ex. i dette Nr. vor naturkyndige Medarbeiders Bedømmelse af Saxilds Bog, som man ser er himmelvidt forskellig fra Hr. Berghs, og dog, uagtet vor Medarbeider godt kjendte Hr. Berghs Anmeldelse, har han ladet den staa - urørt - ved sit Værd. En saadan Forholdsregel tro vi oftere kan og bør iagttages. De tvingende, men ei de paatagende Grunde til Strid mene vi bør her som overalt søges fulgte. ${ }^{62}$

Krogness fortsatte så med å beskrive det han oppfattet å være forskjellen mellom För-
59 Ibid.
60 Ibid.
61 Ibid.
62 Ibid., 150. 
eningen og Wäktaren, og å redegjøre for hvorfor Wäktaren var å foretrekke fremfor det tidsskriftet som Bergh holdt frem. Det hadde overhodet ikke vært deres hensikt å anmelde Föreningen, hevdet han. De hadde bare ønsket å belyse hvordan Wäktaren hadde tatt opp spørsmålet om hva som var hensiktsmessig når det gjaldt tidsskriftenes plan og formål. I og for seg kunne derfor det de hadde skrevet om Föreningen vært utelatt. Men når det var sagt, fortsatte Krogness, var det imidlertid all grunn tilå opprettholde det inntrykket av denne avisen som de hadde skapt i forrige tekst. Noe kunne riktignok sies til Föreningens forsvar: Den kunne med "dygtighed tale opdragelsens sag i hvad der gjælder Borgerskabet paa Jorden". Men når det gjaldt religiøse anliggende stod det langt dårligere til: "[...] ikke med saadan Fasthed og Interesse har den traadt frem, naar Talen gjaldt Optugtelsen til Kristum, Opdragelsen for Borgerskabet heroventil og Nødvendigheden af at Lærerne selv lade sig av den Hellige Aand dagligen opdrage til levende Vidne om deres Herre og Frelser." ${ }^{33}$ Avisen hadde med andre ord en uklar tilhørighet hva angikk det kristne budskap: Den hadde vist seg som rasjonalistisk og uten et fast konfesjonelt standpunkt.

Etter dette gikk Krogness over til å komme Berghs påstander om Wäktaren i møte, og i tekstens neste del blir Berghs anklagende påstander brukt til å tale Wäktarens fordel. Krogness viste her detaljkunnskap om avisen. Å beskylde den for "børneplageri” var en temmelig drøy påstand, mente han. Tvert om talte den varmt om "Børnenes kristelige og kirkelige Ret til sand Opdragelse". I den siste tiden hadde den dessuten gitt en ryddig og sakssvarende fremstilling av Elberfeldskandalen, som i avisene her hjemme hadde blitt omtalt på en ensidig og ukristelig måte. ${ }^{64}$ Den hadde også nylig gitt en lengre fremstilling av den tyske presten og pedagogen Johann Friedrich Flattichs oppdragelsesteori og -praksis, og den hadde anmeldt en rekke skrifter som var utgitt som bidrag til almueskolespørsmålet. Å anklage den for piesteri var også feilaktig; tvertimot var det i avisens forhold til den lutherske kirke og bekjennelse at den viste seg på sitt beste:

\begin{abstract}
Forsaavidt derfor som den skarpt og bestemt lægger det bibelske Ords og vore Bekjendelsesskrifters Maalesnor ud over Læren og Livet, er den pietistisk, men det burde man være noget sen med at lægge En til Last. Vi ved nok, at de nu som i Speners velsignede Dage er kommet i Mode at stemple ogsaa Saadant med Piesteriets Smædeord; men derfor aflade vi og Flere med os ikke at tro, at Pietismen (...) i dens sande og ædle Væsen maa uadskillelig være forenet med den rene lære (...), at Guds ord læres purt og rent, og vi, som det sømmer sig Guds Børn, lade det udtrykkelig tilsyne i vort Levnet. ${ }^{65}$
\end{abstract}

Den sanne pietisme var venn av den troendes venn og kjød av hans kjød, konkluderte Krogness, og dette burde man ha klart for seg både i skole og kirke, i skoleskrift som kirkeskrift, så vel som i hjemmet som utenfor.

Så langt har de som har fulgt ordskiftet mellom Krognesss og Bergh i begrenset grad vært i stand til å forstå omfanget eller temperaturen på konflikten mellom de to periodika i svensk offentlighet. I to svenske brev til Almueskoletidende, som ble gjengitt i en senere utgave av tidsskriftet, ble det klart at det dreier seg om en reell

63 Ibid., 152.

64 Det refereres her til Elberfeldt-systemet for fattigpleie, som hadde blitt innført i Tyskland i 1853.

65 "Skole-Efteretninger," no. 10 (1862), 153. 
strid mellom de to svenske publikasjonene. ${ }^{66}$ Samtidig ble det negative inntrykket som allerede er etablert i dette tidsskriftet hva Föreningen angår, forsterket. Föreningen holdt en usaklig tone i debatten, kan vi lese i det første innlegget. En ting var den "rationalistiska tendens och det osläckliga läsarehat" som preget denne publikasjonen, en annen ting var at den synes å ha gjort det til sin oppgave å "gräla och skälla" på Wäktaren. Denne type pøbelspråk var en fremferd som Föreningen i lengden ville tape på, mente innsenderen. I det andre svenske brevet blir det bildet som Almueskoletidende har tegnet av Föreningen underbygget, slik at leseren sitter igjen med et inntrykk av Föreningen som en utgivelse som gjorde motstand mot sann kristendom. Det mest klanderverdige, hevdet den svenske innsenderen, var den "bitterhet och ofördragsamhet, som Föreningens redaktør visar mot de nu pågående andliga rörelserna i landet, hvilken, huru mycket bristfällig det än må finnas deri, ovedersägligen äro ett verk af Herrans Anda". ${ }^{67}$ Siden Sverige var preget av likegyldighet i forhold til skoleanliggende, og siden så mange foreldre sendte sine barn i skolen av åpenbare plikthensyn, var dette svært beklagelig, mente innsenderen. Imidlertid hadde man i den senere tid sett bevegelser som borget for optimisme: Flere steder i landet var det nylig blitt etablert skole- og oppdragelsesinstitusjoner som var tuftet på sann kristelig oppdragelse.

Forskjellene mellom de to svenske tidsskriftene ble også oppsummert av Föreningens redaktør Fredrik Ekström. I en redaksjonell artikkel i sitt eget tidsskrift kom han inn på den omtalte artikkelen i Wäktaren, der norske Almueskoletidende hadde blitt fremstilt som en ideell skoleavis. Han ønsket å avgrense seg mot flere av påstandene som hadde blitt reist i denne teksten, og mest alvorlig, beskyldningene om at Föreningen hadde manglet "egenskapen af en ädel, strängt sedlig ståndpunkt äfvensom icke klart och bestämdt står på Guds ords och våra bekännelsesskrifters grund". ${ }^{68}$ I den påfølgende utlegningen ble det tegnet et relieff av de kontraster mellom Wäktaren og Föreningen som blir opptatt på samme tid i de norske tidsskriftene. Wäktaren stod for en streng evangelisk-konfesjonell kristendom, mens Föreningen ønsket å fremme en bred og åpen folkedannelse. Wäktaren festet seg dermed ved gale aspekter av den kristne tro, hevdet Ekström, det tilkjennega en forståelse av kristendommen som ikke grep inn i evangeliets kjerne. Föreningen, derimot, gjorde nettopp dette, ved å bredt tematisere folkedannelsens grunnprinsipper. For evangeliet handlet nettopp om å se mennesket og menneskets potensial, mye mer enn det handlet om synd, skyld og menneskets nedarvede ondskap.

Redaktørene av Almueskoletidende og Den norske Folkeskole fant dermed allierte i svensk presselandskap, og gjorde bruk av disse for å tydeliggjøre sine egne posisjoner i aktuell norsk debatt. Almueskoletidende brukte Wäktaren i positiv forstand for å synliggjøre behovet for en presse som var fundert på evangelisk-luthersk grunn, slik som også skolen skulle fundere sin undervisning på denne grunnen. Samtidig brukte de Föreningen til å synliggjøre hva oppdragelse og undervisning ikke skal være. Med Den norske Folkeskole forholdt det seg på motsatt måte. For denne publikasjonen ble Wäktaren en utgivelse som hindret sann opplysning og opplæring i

66 Teksten trykkes i no. 14 (1862), 26-8.

67 Ibid., 27.

68 Fredrik Ekström, "Folkskolan," Föreningen: Tidsskrift för folkskolans och kyrkomusikens vänner (1861), 9 . 
borgerlige fag. Föreningen, derimot, var et tidsskrift som fremmet folks opplysning og folkets dannelse.

\section{Tekstkulturer i bevegelse og denne artikkelens abduktive strategi}

I denne teksten har to empiriske nedslagsfelt vært brukt for å vise hvordan tekstkulturer bandt Norge og Sverige sammen rundt midten av det 19. århundre, og skapte forbindelser mellom landene på skolens område. Tekstkulturene har forskjellig funksjon i de to nedslagsfeltene. I en artikkel fra Morgenbladet i 1855 tok Hartvig Nissen til orde for en ny forståelse av hva han mente religion var. Denne trakk religionen bort fra en dogmatisk bekjennelse, og over til en eksistensiell forståelse av religionens plass i menneskets liv. Dette falt sammen med tanker og holdninger Per Adam Siljeström hadde tatt til orde for i sitt tidsskrift. Dreiningen i Nissens forfatterskap skjedde etter at Nissen har møtt Siljeström i London i 1854. Men like lite som vi med sikkerhet kan fastslå at dreiningen i Nissens forfatterskap var en direkte følge av kontakt mellom Siljeström og Nissen, like mye kan vi med sikkerhet fastslå at ytringer i norsk og svensk presse forenes i sammenfallende konvensjoner om hva religion skal være. For Norges vedkommende forespeiler dette bevegelser som skal gjøre seg gjeldende i tiårene fremover; bevegelser som gradvis fristilte skolen fra kirken og som gjør skolen til en institusjon som i større grad drives på folkets premisser.

Noen år senere brukte Almueskoletidende og Den norske Folkeskole to svenske tidsskrifter for å synliggjøre sin posisjon i det kirkelige, ideologiske og kulturelle landskap i Norge. Wäktaren og Föreningen underbygget deres egne posisjoner; posisjoner som tydeliggjorde spenninger mellom en evangelisk-konfesjonell offentlighet og en folkedanningsoffentlighet i Norge. De norsk-svenske tekstkulturene ble dermed del av en kamp i et ideologisk landskap som er typiske for det samtidige Norge. Tekstkulturene som ble dannet på tvers av landegrensene mellom Norge og Sverige fremstår dermed som dynamiske størrelser. De kan blant annet, som i tilfellet med Nissen, signalisere brudd med etablerte konvensjoner, eller, som i tilfellet med tidsskriftene, tjene til å profilere egne posisjoner i et polarisert ideologisk landskap som allerede eksisterer.

Den abduktive prosessen i denne artikkelen bør dermed også være sporbar. På bakgrunn av empiriske observasjoner kan vi med stor sannsynlighet fastslå at det fantes norsk-svenske tekstkulturer, det vil si offentlige ytringsarenaer med sammenfallende normer, på skolens område rundt midten av det 19. århundre. Disse gikk utover de forbindelser som kan baseres på evidens, for eksempel at Siljeströms beretninger fra reisen til Amerika blir tatt opp i norsk offentlighet på midten av 1850-tallet. De peker også mot nødvendigheten av ytterligere studier av relasjonen mellom Norge og Sverige, både hva skole angår så vel som i forhold til andre områder under unionen mellom de to land. 


\section{Litteratur}

\section{Arkivkilder}

Brev fra Hartvig Nissen til Magdalena (Lena) Nissen, 6. juli 1854. Ubehandlet 147. Nasjonalbiblioteket, Oslo.

Brev fra Per Adam Siljeström til Per Nissen, 9. februar 1874. Ubehandlet 147. Nasjonalbiblioteket, Oslo.

\section{Trykte kilder}

"Beretning om Christiania Almueskolevæsen, udgiven af Selskabet for Folkeoplysningens Fremme." 1ste Tillæggshæfte til Folkevennens 5te Aargang. Christiania (1856).

Bruun, Julius. "Nogle Bemerkninger aangaaende den nye Læsebog for Folkeskolen og Folkehjemmet." Luthersk Kirketidende 8 (1867), 129-48, 241-47, 354-64, 385-97.

Ekström, Fredrik. "Folkskolan." Föreningen: Tidsskrift för folkskolans och kyrkomusikens vänner (1861), 9.

Folkestad, Halvor. "Hr. H. Nissen i forhold til Almueskolesagen." Morgenbladet 16.4.1854.

"Forhandlinger om Almuskolevæsenet." Folkevennen (1855), 185-220.

Grundtvig, N. F. S. "Er troen virkelig en Skole-Sag (1825)." http://grundtvigcenteret.au.dk/fileadmin/www.grundtvigcenteret.au.dk/digitalisering/s_g_i_grundtvigs_skrifter/skolesag.pdf (lest 30.1.2017).

Krogness, Samson M. "Et Ord forud." Maanedstidende for den norske Almueskole, no. 1 (1861), 2-7.

Nissen, Hartvig. "Resa i Förenta Staterna af P. A. Siljeström: Om bildningen i Förenta Staterna. Stockholm 1852. P. A. Norstedt \& Söner. 494 sider." Morgenbladet 11.6.1852 og 13.6.1852.

Nissen, Hartvig. "Hr. Provst Folkestad om Almueskolens Administrationsforholde og om dens forhold til kirke og stat." Morgenbladet 4.8.1853.

Nissen, Hartvig. Beskrivelse over Skotlands Almueskolevoesen: Tilligemed Forslag til forskjellige Foranstaltninger til en videre Udvikling af det norske Almueskolevoesen: (en Indberetning i Anledning en af etter offentlig Foranstaltning foretagen Reise). Christiania: P. T. Mallings Forlag \& Boghandel, 1854a.

Nissen, Hartvig. "Opfordring til Deeltagelse i en Skoleudstilling, som skal holdes i London i næste Maaned." Morgenbladet 11.05.1854.

Nissen, Hartvig. "Skoleudstillingen i London." Morgenbladet 23.05.1854.

Nissen, Hartvig. "Om Skolens, navnlig Almueskolens Forhold til Livet og om Tidens, i dette Forhold begrunnede, Krav til vor Almueskole." Morgenbladet 8.6.1855.

Siljeström, Per Adam. "Folkbildningen - Om religionsundervisningen." Dagens Häfder, 1.10 .1853 .

Siljeström, Per Adam. "Folkbildningen - Om religionsundervisningen." Dagens Häfder, 2.1.1854.

Siljeström, Per Adam. "Handlingar rörande ombildningen af folkskoleväsenet $\mathrm{i}$ Stockholm," i P. A. Siljeström, Handlingar och skrifter rörende undervisningsväsenet, 360-530. Stockholm: P. A. Norstedt \& Söner, 1884.

Siljeström, Per Adam. Resa i Förenta Staterna - Första delen: Om bildningsmedlen och bildningen i Förenta Staterna. Stockholm: s.n., 1852. 
Siljeström, Per Adam. Inledning til skolarkitekturen. Stockholm: s.n., 1856.

Siljeström, Per Adam. Bidrag til skolarkitekturen: Ritningar och beskrifningar öfver skolhus, skolmöbler, undervisningsmedel m. m., til tjenst for skolstyrelser, skolföreståndare, lärare och andre för undervisningsväsenet interesserade personer. Stockhom: s.n., 1856.

Ukjent forfatter. "Boganmeldelser: Föreningen: Tidsskrift för Folkskolans och Kyrkomusikens Vänner. Adr. Köping i Sverige.” Den norske Folkeskole no. 18 (1862), 284-86.

Ukjent forfatter. "Om Behofwet af en god tidning för Folkskolan." Wäktaren 51 (1859).

Ukjent forfatter. "Skole-Efterretninger." Almueskoletidende no. 2 (1862), 29-30.

Ukjent forfatter. "Skole-Efterretninger." Almueskoletidende no. 10 (1862), 150-54.

Uten tittel [Leserbrev]. Almueskoletidende no. 14 (1862), 26-28.

Vig, Ole. "Forord." Den norske Folkeskole: Et Maanedsskrift for Loerere og andre Opdragere (1852), 1-5.

\section{Sekundoerkilder}

Backholm, Johan. "När lärarna blev nordister: Om Skandinavism och Nordism på de första nordiska skolmöterna." Nordisk Tidsskrift, no. 6 (1994).

Bjerstedt, Åke. Självstendighetsmotivet: Ett grundtema i P. A. Siljestrøms reformpedagogik. Lund: Uniskol, 1965.

Boyesen, Einar. Hartvig Nissen (1815-1874) og det norske skolevesenets reform Bind 2: Enkeltreformenes tid. Oslo: Johan Grundt Tanum, 1947.

Dokka, Hans Jørgen. Fra Almueskole til Folkeskole: Studier i den norske folkeskoles historie i det 19. århundre. Oslo: Universitetsforlaget 1967.

Edgren, Henrik. "En främling i den svenska folkskolan: 1870-talets folkskolundervisning i naturkunnighet.” I Sann opplysning? Naturvitenskap i nordiske offentligheter gjennom fire århundrer, red. Merethe Roos og Johan Tønnesson, 211-38. Oslo: Cappelen Damm Akademisk, 2017.

Edgren, Henrik, Ruth Hemstad og Merethe Roos. "Skolehistorie på kartet." Morgenbladet 27.10.2017

Edgren, Henrik, Ruth Hemstad og Merethe Roos. "Gud og naturen." Vårt Land, 9.12.2017.

Eide, Martin, red. Norsk Presses Historie - Bind 1: En samfunnsmakt blir til. Oslo: Universitetsforlaget, 2010.

Ekman, Kari Haarder, "Mitt hems gränser vidgades": En studie i den kulturelle skandinavismen under 1800-talet. Göteborg/Stockholm: Makadam förlag og Centrum för Danmarksstudier 23, 2010.

Habermas, Jürgen. Borgerlig Offentlighet: Dens fremvekst og forfall. Henimot en teori om det borgerlige samfunn, oversatt av Elling Schwabe-Hansen, Helge Høibraaten og Jon Øien. Oslo: Gyldendal, 2002.

Hagemann, Gro. Skolefolk: Lerernes historie i Norge. Oslo: Ad Notam Gyldendal, 1992.

Hemstad, Ruth. Fra Indian Summer til nordisk vinter: Skandinavisk samarbeid, skandinavisme og unionsoppløsningen. Oslo: Akademisk Publisering, 2008.

Hemstad, Ruth, "Geopolitik og geografibøker for folket: Den norsk-svenske unionens besværlige beskrivelser." I Sann opplysning? Naturvitenskap i nordiske 
offentligheter gjennom fire århundrer, red. Merethe Roos og Johan Tønnesson, 101-26. Oslo: Cappelen Damm Akademisk, 2017.

Hemstad, Ruth, Jes Fabricius Møller og Dag Thorkildsen. "Skandinavismen som visjon og påvirkningskraft." I Skandinavismen: Visjon og virkning, red. Ruth Hemstad, Jes Fabricius Møller og Dag Thorkildsen, 9-20. Odense: Syddansk universitetsforlag, 2018.

Hillström, Magdalena og Hanne Sanders, red. Skandinavism: En rörelse och en idé under 1800-talet. Göteborg/Stockholm: Makadam förlag, 2014.

Hovland, Brit Marie. For Fedreland og Broderband: Allmugeskoleloerarane si møteverksem i det nasjonale gjennombrotet 1850-1870. Volda: Norges Forskningsråd, 1997.

Lundahl, Christian. "Swedish Education Exhibitions and Aesthetic Governing at World's Fairs in the Late Nineteenth Century." Nordic Journal of Educational History 3, no. 2 (2016), 3-30.

Mellander, Cathrine. Arkitektoniska visioner under statligt förmyndarskap: En studie av Överintendentsämbetets verksamhet och organisation 1818-1917. Stockholm: Nordiska museets förlag, 2008.

Midttun, Jørund. ”For leg og lærd: En oversikt over norske kristelige tidsskrifter 1800-1895." I Kristelig og borgerlig offentlighet $i$ Norge, red. Tarald Rasmussen og Trygve Wyller, 24-64. Oslo: Norges Forskningsråd, 1996.

Mork, Anne Helene Høyland. Unionen i historieundervisningen: Synet på den svensk-norske union (1814-1905) i svenske og norske loerebøker for folkeskolen $i$ perioden 1860-1920. Diss. Oslo: Universitetet i Oslo. 2005.

Rasmussen, Tarald og Trygve Wyller, red. Kristelig og borgerlig offentlighet $i$ Norge. Oslo: Norges Forskningsråd, 1996.

Roos, Merethe. Kraften i allmenn dannelse: Skolen som formidler av humaniora - Bidrag til en historisk lesning. Kristiansand: Portal forlag, 2016.

Roos, Merethe. "Nogle Bemerkninger aangaaende den nye Læsebog for Folkeskolen og Folkehjemmet: En nylesning av Julius Bruuns tekst i Luthersk Kirketidende 1867." Norsk Pedagogisk Tidsskrift 2 (2018, under utgivelse).

Roos, Merethe. "Å velte en kjempe: Tekstkulturer og modellesere i Nils E. Hertzbergs skrifter." Sakprosa 8, no. 2 (2016).

Ryden, Per og Karl-Erik Gustavsson. Den svenska pressens historia 2: Åren då allting hände (1830-1897). Stockholm: Ekerlids förlag, 2000.

Richardsson, Gunnar. "Torsten Rudenschöld." Prospects 24/3 (1994), 439-53.

Sanderud, Roar. Fra P. A. Jensen til Nordahl Rolfsen: Et skolehistorisk bilde. Oslo: Gyldendal, 1951.

Sjöberg, Gustaf. Bidrag til Nya elementarskolans historia under de första femti åren af hennes tillvare 1 (1828-48). Stockholm: s.n., 1878.

Sjöberg, Gustaf. Bidrag til Nya elementarskolans historia under de första femti åren af hennes tillvare 2 (1849-1878). Stockholm: s.n., 1885.

Slagstad, Rune. De nasjonale strateger. Oslo: Pax, 2001.

Svennevig, Jan. "Abduction as a Methodological Approach to the Study of Spoken Interaction." Norskrift 103 (2001), 1-22.

Thorkildsen, Dag. Nasjonalitet, identitet og moral. Oslo: KULT’s skriftserie, 1995.

Thorkildsen, Dag. "Skandinavismen - en historisk oversikt." Nasjonal identitet - et kunstprodukt, red. Øystein Sørensen, 191-209. Oslo: KULT’s skriftserie, 1994. 
Tønnesson, Johan, red. Den flerstemmige sakprosaen. Oslo: Fagbokforlaget, 2002.

Tønnesson, Johan. Hva er sakprosa. Oslo: Universitetsforlaget, 2012.

Tønnesson, Johan. "Naturvitenskapens kommunikative landskap: Teksthistorisk blikk på det fjerde naturforskermøtet, Christiania 1844." I Sann opplysning? Naturvitenskap i nordiske offentligheter gjennom fire århundrer, red. Merethe Roos og Johan Tønnesson, 163-90. Oslo: Cappelen Damm Akademisk, 2017.

Ukjent forfatter. "Ännu en skolvetran." Svensk läraretidning: Veckoblad för lärare, uppfostrare och skolvänner, no. 22. 18.6.1891. http://runeberg.org/svlartid/1891/0233.html

Ulvund, Frode. "Travelling Images and Projected Representations: Perceptions of Mormonism in Norway 1840-1860." Scandiavian Journal of History 41, no. 2 (2016), 208-30.

Wennås, Olof. Striden om latinväldet: Idéer och intressen i svensk skolpolitik under 1800-talet. Stockholm: Almqvist \& Wiksell, 1966.

Westberg, Johannes. Att bygga ett skolväsende: Folkskolans förutsetninger och framväxt 1840-1900. Lund: Nordic Academic Press, 2015. 